\title{
Celebrating Difference: The Self as Double in the Works of Louise Labé
}

CATHERINE M. MÜLLER

Summary: This essay examines the figure of the double in Sonnet VIII of Louise Labé in relation to the theme of the androgyne in the Débat de Folie et d'Amour and in the light of the proto-feminist claims of her "Épitre Dédicatoire." It suggests that the poet from Lyon, in inscribing dialogue at the very heart of her Oeuvres as the motive force of an écriture du plaisir, opposes herself to the literary tradition of her age and heralds the great debates of the twentieth century regarding sexual difference and literary subjectivity.

Tatalie Zemon Davis has shown that although it was rare for noblewomen to write and publish during the French Renaissance and Reformation, it was almost inconceivable for a middle-class woman to do so. ${ }^{1}$ Yet Louise Labé, daughter and wife of ropemakers, encouraged by the somewhat open-minded environment of the great humanistic city of Lyon and compelled by a desire to show the public that it was time for women's voices to be heard, published her complete works in her own name with the best known publishing house of the time. In 1555, her Oeuvres came out in Lyon with the prestigious "Privilège du Roy" she had requested, i.e., an exclusive publishing right, so that no one could print her works without her prior consent. ${ }^{2}$ The Oeuvres contain five sections: her "Épître Dédicatoire," a polemical defense of women addressed to a young noblewoman of Lyon; her Débat de Folie et d'Amour, a comical treatise on love; three Elegies; 24 Sonnets; and a series of anonymous poems written by various male authors honoring her as the new French Sappho. This mixture of styles and voices 
is, I believe, at the very core of Labé's proto-feminist program, as it reveals a desire to subvert the literary tradition of the sixteenth century from within by establishing a dialogue with the major figures of this tradition. Her daring works raise issues of sexual difference and subjectivity and propose a powerful model of and for female authorship. In this brief study, I will show how the dialogic strategies employed in her Débat de Folie et d'Amour and the concept of subjectivity as double, manifested in particular in Sonnet XVIII, serve as a basis for the proto-feminist thoughts of her "Épître Dédicatoire" and prepare the way for many twentieth-century debates on gender issues.

As a preface to Labé's complete works, the dedicatory Epistle encourages women to take advantage of the learning made available to them and to devote their time to studying and writing in order to acquire "gloire," "honneur," and "plaisir." She adds that men too will benefit from this:

Et outre la reputacion que notre sexe en recevra, nous aurons valù au publiq, que les hommes mettront plus de peine et d'estude aus sciences vertueuses, de peur qu'ils n'ayent honte de voir preceder celles, desquelles ils ont pretendu estre tousjours superieurs quasi en tout. (p. 42)

In an indirect way, men are thus also being encouraged to excel. They are included in Labé's literary work as well, albeit anonymously, by means of the poems they dedicated to her. Throughout her Oeuvres, Labé insists on the importance of communication with the Other, both male and female. By the presence of these mixed voices in her works, she fosters dialogue and envisages a community of learning, where difference is celebrated not only between men and women, but also between women and within each woman, foretelling in a way the threefold program proposed by Rosi Braidotti. ${ }^{3}$ Labé's texts invite women to recognize and enjoy the Other within, so that outward communication with other Selves can be achieved without any need for appropriation or any fear of difference. In her Elegies and her last Sonnet she stresses the difference between women by addressing different ladies who may not approve of and may even condemn her. She manifests the difference within woman in nearly all of her lyrical works and in the Débat, when she discusses the alienating power of love.

The Débat de Folie et d'Amour illustrates the "Épître Dédicatoire" and celebrates difference. A brief summary of the Débat is in order. Amour and Folie both arrive late to a banquet given by Jupiter in Amour's honor. Folie, who does not wish to be last, pushes Amour aside. A squabble begins that ends with Folie plucking out Amour's eyes and then bandaging them to 
reduce their repulsiveness. Amour's mother Venus hears his lament and calls to Jupiter for justice. A court is summoned, and Folie chooses Mercury to represent her, whereas Apollo represents Amour. As Robert Cottrell has shown in his Lacanian reading of the Débat, Amour is effectively portrayed as a male protagonist trapped in the imaginary, in a perfect symbiosis with the mother (Venus), until the castrating intervention of Folie propels him into the symbolic, where he lives in a nostalgic longing for perfect, re-created unity with his first love. (Cottrell reminds us that the fear of castration is associated with the "fear of blindness" in psychoanalytic dream imagery. ${ }^{4}$ ) Apollo's speech links Amour with the concepts of order, stasis, harmony, univocity, and conservatism, while Folie, according to Mercury, personifies movement, change, plurality, and chaos.

Furthermore, as Julianne Jones Wright and François Rigolot have suggested in their feminist reading, Folie becomes an embodiment of the female voice of the "Épître Dédicatoire," as she asserts her authority and demands respect. ${ }^{5}$ At the outset of her encounter with Amour, she affirms her power and superiority. Amour, Venus, and Apollo criticize her not only for speaking arrogantly, but also for speaking at all, for usurping a forbidden "parole." Wright and Rigolot note four instances in which Folie interrupts Mercury because she cannot keep from speaking in her own name and must reclaim the voice refused her by the patriarchal system. Besides, she has carefully instructed Mercury how to speak. He is not to use any rhetorical device to persuade the gods, because she wants to privilege truth over a flowery style. By analogy, the Epistle stresses the need for women to place more importance on internal beauty and knowledge than on vain ornaments of the body. In opposition, rhetorical effects and outward appearance are Apollo's main emphases. Folie also prohibits Mercury from arousing sympathy by portraying her as a weak, pitiful, and powerless creature. Moreover, Folie makes a deliberate attempt to dissociate herself from the phallocentric representation of women exemplified by the behavior of Venus, who cries and confesses that she cannot speak because of her overwhelming grief.

By contrast, Labé's persona in her lyrical works appears as a woman smitten by love but never victimized. If she grieves, it is by choice, to keep the memory of her love alive and relive it in her body. A close comparison between Labé's Elegies and the elegiac tradition from Ovid to Boccaccio and Nicolò da Correggio reveals the determination of the Labean persona to stay in control of her suffering and turn it into a song. ${ }^{6}$ Even Sappho herself - under whose sign Labé presents her poetic voice and with whom she was 
associated during her lifetime - confesses in Ovid's Heroides (Letter XV, "Sappho Phaoni") that she is no longer capable of singing and writing because she has been so weakened by love's power. As Deborah Lesko Baker has argued in her articles on Labé's poetry, the speaker in the Sonnets refuses to be compared to the mourning, "tortured" lover of the Neoplatonic tradition - more specifically that of Petrarch and Scève - and systematically deconstructs these masculine models, revealing a powerful "integrated self," who celebrates the possibility of a fulfilling love here and now and expresses confidence in her own artistic abilities. ${ }^{7}$

I wish to stress that my application of the word "celebrate" to the Débat is motivated specifically by the character of Folie, who is said to be always amusing, always entertaining, singing, playing, acting out, dancing, and laughing. Building on Cottrell's image of the castrating Medusa, ${ }^{8}$ I would call her a "laughing Medusa," Hélène Cixous's symbol for an empowered woman who claims her own multiple voice, denounces the unique and unified male subject (embodied by Amour), and defies the logic of phallogocentric discourse (represented by the male gods). ${ }^{9}$ Opposing Apollo's speech in defense of Neoplatonic love, Folie - by means of and together with Mercury, the god of movement and eloquence - proves the absurdity of such love and contrasts it with an untamable fury, which is both a desire for a tangible, sensual amorous exchange and a desire to express love through artistic creation. Movement, change, laughter, desire, chaos are all attributes which frighten Amour and threaten to cut him off from his mother and his illusion of perfect oneness and harmony: he repeatedly states his fear of the danger Folie represents to him.

The outcome of the Débat is one of Labé's most powerful claims for difference, because it refutes the traditional closure prescribed by the genre. By emphasizing Jupiter's incapability to pronounce a definite judgment, Labé disempowers the patriarchal voice, which was supposed to have final authority and reestablish order among gods and humans. In effect, she allows Folie to be Amour's guide forever, thereby stressing the helplessness of the male without the female and the danger of harmony and univocity without the elements of chaos and plurality. Even by means of the indeterminacy of the pronoun "lui" in "Et guidera Folie l'aveugle Amour, et le conduira par tout ou bon lui semblera" (p. 103) - "lui" designating both the feminine and masculine protagonists - the text privileges ambiguity and non-closure. This undecidability between male and female subjects, and between traditional masculine and feminine elements, is frequent in Labé's poetry. For 
instance, she repeatedly uses the metaphor of the sun for the woman and the moon for the man, or associates the figure of Orpheus with the female, ${ }^{10}$ or even plays on the indeterminacy of signs, as she does in her very well known first French Sonnet, "O beaus yeus bruns," where the attributes can designate either the lover or the beloved, or both. Moreover, Rigolot demonstrates how Labé plays with gender categories, especially with the word "amour," both masculine and feminine in the Renaissance, and systematically appropriates the gender that best allows her to illustrate her own concept of love and to affirm her identity as a female speaker and writer. ${ }^{11}$

The double nature of love at the end of the Débat - wherein Amour and Folie walk as one but remain two different beings - coupled with the feminine principle acting as both agent (it is she who has blinded Amour) and enabler (it is she who now guides him), becomes a powerful model for Labé's subversive ideological project. That project involves debunking the system of male representation of women - exemplified by the Neoplatonist writings of her time - and offering a new figuration for the female voice through the image of openness and ambivalence. To use Laurie A. Finke's terminology, Labé is "creating noise" in refusing, like Folie, to be silenced by the patriarchal law. ${ }^{12}$

In Sonnet XVIII, the poet's strategy of defining love as double allows her to question the subject-object paradigm within the traditional love discourse and to propose a new model of subjectivity for women. The first consequence of love as fury is a blurring of the categories of Self and Other characterized by a crisis of the subject, which Labé calls "estrangement," an estranging or alienating force causing the individual no longer to recognize him- or herself. ${ }^{13}$ Labé insists that the folly of love destabilizes the most securely anchored reason and creates havoc in what humans think to be fixed categories, like that of the unified Self. Suddenly chaos enters and the Self becomes a locus of the Other, the different, the unknown. This embodiment within the psyche of love-as-estrangement is a strategic way for Labé to demonstrate that love is an agent of change, an opportunity for the subject to experience otherness within the Self, or the Self as Other. It is a necessary step toward acquisition of subjectivity in the symbolic, because it unleashes a desire for both the Other and the same, allowing for true communication not only with the lover, but with all Others. As Folie states in the Débat, "Le plaisir que donne Amour, est caché et secret: celui de Folie se communique à tout le monde" (p. 89). In order to feel and express the pleasure of love, the subject has to experience the reality of otherness within. One has to 
become a double subject to be able to live out what Labé in Sonnet XVIII calls a "double vie."

Sonnet XVIII is central to Labé's Oeuvres in part because it establishes a link with both the past and the present - that is, respectively, with the tradition of Latin texts on the basium and with the poem "De Aloysae Labaeae Osculis" included among the texts written in her honor. ${ }^{14}$ As Rigolot has argued, the play on the words "basia," "labea," "labaeae," "osculis" in the contemporary Latin poem associates her name Labé with the lips who kiss and the lips who sing poetry. ${ }^{15}$ In Sonnet XVIII, Labé employs the image of kissing to inscribe herself in the text - as lover and poet - and in the literary tradition, as she responds to the male writers while asserting her feminine voice. At the same time, this sonnet is crucial to Labé's feminist program because it stresses her departure from the Neoplatonic concept of love, with its emphasis on the myth of the androgyne as a symbol of perfect spiritual unity between lovers. Throughout this poem, Labé deconstructs that myth and appropriates a new definition of doubleness, as she engages in dialogue with the works of Ovid, Ficino, Ebreo, ${ }^{16}$ and Petrarch, as well as with her highly acclaimed fellow Lyonnais Maurice Scève. Ultimately, by recalling the "Épître Dédicatoire" and the Débat, this poem proposes a new concept of Self and a form of art poétique which provides a model for women as readers of her works and as writers of their own:

Baise m'encor, rebaise moy et baise:

Donne m'en un de tes plus savoureus,

Donne m'en un de tes plus amoureus:

Je t'en rendray quatre plus chaus que braise.

Las, te pleins tu? ça que ce mal j'apaise,

En t'en donnant dix autres doucereus.

Ainsi meslans nos baisers tant heureus

Jouissons nous l'un de l'autre à notre aise.

Lors double vie à chacun en suivra.

Chacun en soy et son ami vivra.

Permets m'Amour penser quelque folie:

Tousjours suis mal, vivant discrettement,

Et ne me puis donner contentement,

Si hors de moy ne fay quelque saillie. 
By starting the poem in medias res, ${ }^{17}$ Labé assigns a status of non-opening and non-closure, a denial of origin and completion, not only to the act of kissing, but to the poem and to the gesture of writing itself. In fact, the very presence of "encor" at the outset of the incipit calls into existence a prior scene or "avant-texte," while the addition of "baise" - without any object or any "re" after "rebaise moy" - suggests a new beginning where one would expect a linear and logical progression. Furthermore, the triple reiteration of "baise," coupled with the emphasis on "re" provoked by the alliteration and the forced, slowed-down pronunciation of "encor, rebaise," establishes repetition between non-opening and non-closure as a key element of both amorous and poetic exchange. Repetition overflows the first line and is made even more insistent by means of the almost identical second and third lines, the rich rhyme ("savoureus"/"amoureus"), and the double recalling of "m'en" from " $m$ 'encor." In line 4, the two " $r$ "s of "rendray" create one more echo of the strong " $r$ " in "encor, rebaise," ascribing to the act of reciprocation an unceasing repetition. Moreover, the number "quatre," as a multiple of the two kisses given in the previous two lines, frames the scene with a sense of endlessness and excess undermining the very numerology it employs. The use of the future may be regarded here as an ironic gesture to oppose the unreachable, spiritual reality of Neoplatonic love with an immediate, tangible, and reciprocal passion. As Baker has shown, the evocation of fire in this line to accentuate the intensity of pleasure represents yet another element of departure from the Petrarchan lyric, where torturous burning is always a result of the beloved's cruel silence or absence. The binary structuring of line 5, with the repetition of "Las" and "ça," introduces a playful dialogue between lovers, as it incorporates the voice of the beloved within the text through a rewording of his lament. Here again Baker has pointed out the irony of the Petrarchan lament's becoming a plea for more kisses and the use of "apaiser" for sexual fulfillment, whereas in Petrarch it denotes the final rest of the lover after death! ${ }^{18}$ Labé renders dialogue with the beloved possible in order to emphasize the mutually fulfilling nature of their exchange and her desire as a poet to inscribe the voice of the Other in her text.

Labé regularly incorporates otherness in her poetry to stress the need for literature to become a place not of univocity but of communication. As Mercury states, Folie is "tousjours ouverte" (p. 82), and so is Labé's textual economy. Openness to the voice of the Other allows for reciprocity. This is underlined in the second quatrain by a series of formal devices: the use of "donnant" to echo the imperatives "donne" from the beginning of the poem; 
the participle "meslans," which like "donnant" connotes continuity as well as togetherness; the reiteration of "nos," "nous" and "notre" - rarely used in either Petrarch or Scève; and finally the form "l'un de l'autre." The repeating of "baisers" adds not only to the number of kisses and to the endless pleasure, but also to the reciprocal nature of that pleasure. In addition, the hyperbolic words "tant heureus" place this exchange under the sign of happiness and excess, an immeasurable and uncontainable love. In Labé's text, this mad love resists counting, the kisses being freely given and multiplied as quickly as one in line 2 becomes ten in line $6 !^{19}$ The first two quatrains depict the couple under the auspices of total well-being and reciprocity, not giving opposition, dissatisfaction, or power-play a chance.

Through the conjunction "Lors," the "double vie" in line 9 is shown to be a result of the mutual jouissance described in the two quatrains. The first tercet introduces the speaker's philosophical view on the issue of subjectobject relation through love. For Labé's contemporaries, the adjective "double" almost inevitably alluded to the myth of the androgyne. This allusion was even more immediate for the reader of the Labean Oeuvres, since in the Débat (p. 70), Apollo had just reminded his divine audience of the story of those Urmenschen, who, according to Aristophanes in Plato's Symposium, were created both male and female as spheres with two faces, four arms, and four legs, and then divided in two by the gods as a punishment, thus provoking a longing for the opposite sex - the other-as-same - that could be satisfied only by a reuniting love. The myth of the androgyne enjoyed great popularity in the Renaissance, as Judeo-Christian elements merged with Plato's comic tale to create a new spiritual ideal of complete oneness and indistinction between perfect lovers.

Labé evokes this myth but situates double life in the realm of the body, which for her is the true source of jouissance, physical and spiritual. She purposefully links the concept of bisexuality with Folie ("Permets m'Amour penser quelque folie"), whom, as we have seen, she associates with difference and chaos. Labé's double life thus takes on a double meaning: through the connection with the quatrains, the reality of a fulfilling love exchange becomes in the tercets a celebration of difference justified by the weaving of madness in the text. This new definition of love is ambiguously both love as a concept and love as a reality. Peggy Kamuf's translations call attention to the threefold meaning of "Permets m'Amour": "Permit me, Love"; "Permit my love"; "Permit me, ... my love". ${ }^{20}$ In Labé's Oeuvres, the signifier Amour is consistently shifting between the lover, the beloved, and 
the fury - the source of inspiration. Through the juxtaposition of " $m$ ' Amour" and "penser," this new definition of love becomes a place where thinking can emerge, philosophical thought that includes Folie as a catalyst of difference. In this love equation there is no chance for two to become one. Rather, as in the "échange amoureux" described by Luce Irigaray, One plus One never equals One or Two, but Three as a symbol of excess and creation. ${ }^{21}$ Similarly, Labé creates an image for a relationship where Self and Other are together in a mutual exchange but never disappear in a oneness that would absorb or destroy otherness. Each lover remains both Self and Other ("chacun en soy et son ami vivra") because each has learned to be another to his/her own Self through the experience of estrangement described above. The economy of desire in this poem is not a dream of unity, but a celebration of doubleness as a symbol of difference and multiplicity.

The real madness of this thinking is made explicit in the last tercet where Labé's philosophy transcends the couple and becomes a new standpoint on the possibility of communication with others through love and writing. The expression "faire saillie" is multifaceted. On the one hand, as Rigolot reminds us, it designates both the copulation of animals and a strategic military attack to force an assailant to withdraw. ${ }^{22}$ In Labé's first Elegy, the term "saillir" refers to the power coming out of the female protagonist's eyes to conquer the beloved. The idea of conquest through the eyes appears also in Sonnets VI and XXIII, where once more the myth of the passive and weak Neoplatonic lover is deconstructed by the poet and replaced by a powerful persona, who is the agent, not the victim, in the innamoramento scene which Mercury mocks in the Débat. Moreover, by associating the light of the eyes with the light of the sun, the symbol of inspiration in other sonnets, the poet establishes a connection between the "saillie" as power of love and the "saillie" as poetic expression.

Curiously, Montaigne too links the word with artistic creation and with a living outside of self: "Les saillies poëtiques, qui emportent leur autheur et le ravissent hors de soy, pourquoy ne les attribuerons nous à son bonheur?"23 This literary meaning of "saillie," as well as its connection with the idea of rapture and happiness, establishes a correspondence between the "Épître Dédicatoire" and Sonnet XVIII. In the Epistle, the word "contentement" designates the pleasure of reading and writing:

S'il y ha quelque chose recommandable apres la gloire et l'honneur, le plaisir que l'estude des lettres ha acoutumé donner nous y doit chacune inciter: qui est autre que les autres recreations: desquelles quand on en ha pris tant que lon veut, on ne se peut vanter 
d'autre chose, que d'avoir passé le tems. Mais celle de l'estude laisse un contentement de soy, qui nous demeure plus longuement. Car le passé nous resjouit, et sert plus que le present: mais les plaisirs des sentimens se perdent incontinent, et ne reviennent jamais. ... Mais quand il avient que mettons par escrit nos concepcions ... si est ce que long tems apres, reprenans nos escrits, nous revenons au mesme point, et à la mesme disposicion ou nous estions. Lors nous redouble notre aise: car nous retrouvons le plaisir passé qu'avons ù ou en la matiere dont escrivions, ou en l'intelligence des sciences ou lors estions adonnez. Et outre ce, le jugement que font nos fecondes concepcions des premieres, nous rend un singulier contentement. (pp. 42-43, emphasis mine)

The verb "redouble" is also associated with jouissance and followed by the same "notre aise" as in Sonnet XVIII.

I suggest that Labé alludes to this passage of the Epistle in her Sonnet to link the concepts of love and writing through that of pleasure. In line 13 of the poem, contentment goes beyond the idea of the couple by a stylistic means whereby "donner" - which previously appeared exclusively in the context of a love gift - now appears in conjunction with the reflexive "me" to focus on the fulfillment of the independent subject. The pronoun "tu" has completely disappeared in the last three verses. What is at stake now is her identity as woman and as poet. If she cannot come outside of herself as Self, she cannot find the contentment she promises in her Epistle. ${ }^{24}$ With her body (the quatrains) and her thinking (the tercets), she needs to embrace the Other within - first, to come out of the Self dynamically and powerfully (as "faire saillie" suggests), then to be able to relate to others, allowing their Selves to live a "double vie" of their own. If she does not express herself, she risks falling not only into a "mal-aise," as is implied by the adverb "mal," but, more dramatically, into a loss of being altogether, as Kamuf reads it - a "mal-être" further emphasized by the quantifier "tousjours," in striking contrast to the "tant heureus" of line 7. The adverb "discrettement" is another of Labé's rich terms, as it can assume three meanings in the sixteenth century: "separately," "prudently," and "reasonably" - all opposed to the connotations of "folie." If the speaker does not take on the attributes of folly and come out of herself but rather stays separate, prudent, and reasonable, she loses her "aise" and "contentement" and becomes a non-being, a non-subject. ${ }^{25}$ The acquisition of subjectivity for the female persona of this text is thus shown to be the coming out from the realm of oneness, from the imaginary symbolized by the androgynous relationship between Amour and his mother Venus. By thinking the mad thought of difference, the feminine Self can claim access to the symbolic and enter the realm of a "saillie poétique." 
Kamuf was the first to establish a parallel between this sixteenth-century proto-feminist and our postmodern feminist theories when she cited Labé's "double vie" as a model for dialogue between men and women in feminism. ${ }^{26}$ I would like to propose, in conclusion, that Labé's contention with the Neoplatonic view of the androgyne, i.e., her replacing of oneness with doubleness, offers striking analogies with some post-structuralist debates on sexual difference, and, more specifically, with contemporary appropriations of the androgyne as a model for the representation of female subjectivity. The myth of the androgyne became popular in feminist theory in the 1970 s as a reaction to radical feminism, which emphasized a reversal of patriarchal hierarchies. Eager to dismantle dualistic oppositions, critics such as Carolyn Heilbrun used the androgyne as a symbol of harmony, as a locus of potential dialogue between the sexes, wherein oppositions would be blurred and thus overcome. ${ }^{27}$ Their opponents, like Cynthia Secor ${ }^{28}$ and Daniel Harris, ${ }^{29}$ although stressing the necessity to eradicate dualistic models of representation, viewed the androgyne - a "static image of perfection, in eternity" 30 - as a threat to feminist theory because it perpetuated the binary opposition masculine/feminine and continued to define women in relation to men, thereby preventing autonomous figurations of female subjectivity.

Today, some postmodern feminists have suggested new models to translate their desire for a creative dialogue between gender categories while accounting for differences. Finke's notion of dialogic feminism and complexity, Katherine Hayles's concept of chaos, ${ }^{31}$ and Braidotti's image of nomadism are all contemporary analogies to Labé's paradigm of double life, inasmuch as they attempt to construct the female subject while "displacing boundaries." 32 Finally, I would like to recall Cixous, who, in "Le rire de la Méduse," translates most eloquently the necessity to travel from a notion of "self effacing, merger-type bisexuality," which she calls "bisexualité neutre," to what she designates as "l'autre bisexualité" or "l'Amour Autre," which represents a "nonexclusion either of the difference or of one sex ..., a multiplication of the effects of the inscription of desire over all parts of my body and the other body." ${ }^{33}$ Labé's concept of jouissance, like that of Cixous, begins as an inscription of desire in the body ("Baise m'encor, rebaise moy et baise") and is reduplicated in the body of the text, when amorous lips offering endless kisses are doubled by Labean lips generating open-ended songs for the double pleasure of bringing contentment to herself and redoubling our own "plaisir du texte." 34

Université de Lausanne 


\section{Notes}

1. Natalie Zemon Davis, Society and Culture in Early Modern France: Eight Essays (Stanford: Stanford University Press, 1975).

2. Louise Labé, Oeuvres complètes: Sonnets, Elégies, Débat de Folie et d'Amour. Poésies, ed. François Rigolot (Paris: Flammarion, 1986). All quotations are from this edition and are incorporated parenthetically in the text.

3. Rosi Braidotti, Nomadic Subjects: Embodiment and Sexual Difference in Contemporary Feminist Theory (New York: Columbia University Press, 1994), pp. 158-67. Braidotti strives to "asser[t] the positivity of sexual difference" and define woman as "other-than a nonman" (p. 161). To achieve this definition, she says, it is necessary to consider the following three levels of sexual difference: 1) "difference between men and women"; "difference among women"; and 3) "differences within each woman."

4. Robert D. Cottrell, "The Problematics of Opposition in Louise Labé's Débat de folie et d'amour," French Forum, 12 (1987), p. 37.

5. Julianne Jones Wright and François Rigolot, "Les Irruptions de Folie: fonction idéologique du porte-parole dans les Oeuvres de Louise Labé," L'Esprit créateur, 30.4 (1990), p. 72.

6. For the two Italian authors, see Giovanni Boccaccio, The Elegy of Lady Fiammetta, trans. M. Causa-Steindler and T. Mauch (Chicago: University of Chicago Press, 1990), and Nicolò da Correggio, Rime, ed. Antonia Tissoni Benvenuti, Scrittori d'Italia 244 (Bari: Laterza, 1969).

7. Deborah Lesko Baker, "Re-reading the folie: Louise Labé's Sonnet XVIII and the Renaissance Love Heritage," Renaissance and Reformation/Renaissance et Réforme, 17.1 (1993), p. 11. See also her article, "Louise Labé's Conditional Imperatives: Subversion and Transcendence of the Petrarchan Tradition," The Sixteenth Century Journal, 21 (1990), pp. $523-41$.

8. Cottrell, p. 38.

9. Hélène Cixous, "Le Rire de la Méduse," L'Arc, 61 (1975), pp. 39-54. For an English translation, see "The Laugh of the Medusa," trans. Keith Cohen and Paula Cohen, in The Signs Reader: Women, Gender, and Scholarship, ed. Elizabeth Abel and Emily K. Abel (Chicago: University of Chicago Press, 1983), pp. 279-97.

10. Of course, she is not the first poet to do so; medieval writers before her had stressed the female side of Orpheus or portrayed heroines as Orphic figures.

11. François Rigolot, "Gender vs. Sex Difference in Louise Labé's Grammar of Love," in Rewriting the Renaissance: The Discourses of Sexual Difference in Early Modern Europe, ed. Margaret W. Ferguson, Maureen Quilligan, and Nancy J. Vickers (Chicago and London: University of Chicago Press, 1986), pp. 287-98, esp. p. 297.

12. Laurie A. Finke, Feminist Theory, Women's Writing (Ithaca, NY: Cornell University Press, 1992), p. 33.

13. “Ainsi Amour de toy t'a estrangee, /Qu'on te diroit en une autre changee" (p. 109). Labé refers also to an "estrange et forte passion" (p. 135) and employs the terms "aliené" (p. 98), as well as multiple expressions denoting metamorphoses and transformation due to the overwhelming power of love (pp. 52, 98-100, 117). 
14. Labé, Oeuvres, pp. 142-45.

15. François Rigolot, "Signature et signification: Les baisers de Louise Labé," Romanic Review, 75.1 (1984), p. 15.

16. See, in particular, Léon Hébreu, Dialogues d'Amour, trans. Pontus de Tyard (Lyon, 1551).

17. Rigolot, "Signature et signification," p. 17.

18. Baker, p. 8.

19. Cf. Peggy Kamuf, "A Double Life (Femmeninism II)," in Men in Feminism, ed. Alice Jardine and Paul Smith (New York and London: Methuen, 1987), p. 94.

20. Ibid., p. 93.

21. Luce Irigaray, Ce Sexe quin'en est pas un (Paris: Minuit, 1977). See also Kamuf, pp. 95-96.

22. Rigolot, "Signature et signification," p. 19.

23. Montaigne, Essais, ed. V.-L. Saulnier (Paris: Presses Universitaires de France, 1965), I, 24 , 174; quoted also in Baker, "Re-reading," p. 14.

24. Cf. Kamuf, p. 95.

25. Ibid., p. 95.

26. Ibid., p. 96.

27. Carolyn G. Heilbrun, Toward a Recognition of Androgyny (New York: Knopf, 1973).

28. Cynthia Secor, “Androgyny: An Early Reappraisal," Women's Studies, 2 (1974), pp. 161-70.

29. Daniel A. Harris, “Androgyny: The Sexist Myth in Disguise," Women's Studies, 2 (1974), pp. 171-84.

30. Secor, p. 164.

31. Katherine Hayles, Chaos Bound: Orderly Disorder in Contemporary Literature and Science (Ithaca, NY: Cornell University Press, 1990).

32. Elizabeth Weed, quoted in Kamuf, p. 96.

33. Cixous, "Laugh of the Medusa," p. 288; "Le Rire de la Méduse," p. 46.

34. Roland Barthes, Le Plaisir du texte (Paris: Seuil, 1973). 